\section{Challenges of sanitary compliance related to trade in products of animal origin in Southern Africa}

\author{
Kudakwashe Magwedere, ${ }^{1,2}$ \\ Tembile Songabe, ${ }^{2}$ Francis Dziva ${ }^{3}$ \\ 'Division of Veterinary Public Health, \\ Directorate of Veterinary Services, \\ Mariental, Namibia; \\ 2Department of Agriculture, Forestry and \\ Fisheries, Directorate of Veterinary \\ Public Health, Pretoria, South Africa; \\ ${ }^{3}$ School of Veterinary Medicine, The \\ University of the West Indies, St \\ Augustine Campus, Trinidad and Tobago
}

\section{Abstract}

Irrespective of the existence of potentially pathogenic organisms carried by animals, foods of animal origin remain the prime nutrition of humans world-wide. As such, food safety continues to be a global concern primarily to safeguard public health and to promote international trade. Application of integrated risk-based quality assurance procedures on-farm and at slaughterhouses plays a crucial role in controlling hazards associated with foods of animal origin. In the present paper we examine safety assurance systems and associated value chains for foods of animal origin based on historical audit results of some Southern African countries with thriving export trade in animal products, mainly to identify areas for improvement. Among the key deficiencies identified were: i) failure to keep pace with scientific advances related to the ever-changing food supply chain; ii) lack of effective national and regional intervention strategies to curtail pathogen transmission and evolution, notably the zoonotic Shiga toxin-producing Escherichia coli; and iii) a lack of effective methods to reduce contamination of foods of wildlife origin. The introduction of foods of wildlife origin for domestic consumption and export markets seriously compounds already existing conflicts in legislation governing food supply and safety. This analysis identifies gaps required to improve the safety of foods of wildlife origin.

\section{Introduction}

The provision of safe food is a fundamental human right enshrined in international law and national constitutions, and thus it guarantees national security and the promotion of develop- ment in Africa (FAO, 2006). Indeed, trade in safe and good quality food safeguards public health, food security and economic development, and if collectively sustained, leads to poverty alleviation. Guaranteeing the safety of livestock products along the production chain is central to the sustenance of the livestock industry. Improvement in food safety to meet consumer and societal demands was facilitated by the liberalisation of the global trade, changing ecosystems and a spate of adulterated food exports (Thompson and Ying, 2007). In response to a steady increase in the standards of food safety, public health concerns and the growing influence of consumers' demands, a tendency to link up livestock products with safety assurance improvement criteria is gaining momentum in most countries worldwide.

\section{Governance and food safety in international food chains}

There are two specific agreements generally dealing with food safety, animal and plant health and product quality policies that are applicable to the World Trade Organization (WTO)'s 160 members as of June 2014 (http:/www.wto.org/english/thewto_e/whatis_e /tif_e/org6_e.htm). Both agreements attempt to identify and address the need for the application of standard trading policies, but at the same time these fail to directly address the issue of protectionism (WTO, 1995). The agreement on the application of sanitary and phytosanitary (SPS) measures of the WTO sets out the basic rules for food safety and protecting animal and plant health in the context of international trade and also procedures for settling disputes (STDF, 2011). To some extent, members can apply a precautionary principle, which is some kind of safety first approach to deal with scientific uncertainty (WTO, 1995; Mukumba and Hornsby, 2011), but this remains inadequate. In order to fulfill the transparency provisions of the SPS agreement, member countries are required to notify changes in sanitary measures and provide information in accordance with the provisions of Annex B of the SPS agreement. Notifications are considered as a key transparency mechanism that seeks to make trade and regulatory authorities aware of new legislation emerging from member states (Mukumba and Hornsby, 2011). Although governments can add any other international pieces of legislation or agreements that may be open to all WTO members, member countries are encouraged to use international standards, guidelines and recommendations (harmonisation) developed by the Codex Alimentarius, World Organization for Animal Health (OIE) and International Plant Protection Convention (IPPC) as indicated in an annex to the WTO SPS Measures Agreement. The Codex Alimentarius Commission develops guidelines
Correspondence: Francis Dziva, School of Veterinary Medicine, University of the West Indies, St Augustine, Trinidad and Tobago. Tel: +868.645 .2640 - Fax: +868.645 .7428 .

E-mail: francis.dziva@sta.uwi.edu

Key words: Meat; Food safety; Hazards; Southern Africa.

Conflict of interest: the authors declare no potential conflict of interest.

Funding: the authors wish to thank the Campus Research and Publication Fund, The University of the West Indies, St Augustine for meeting the publication costs of this article.

Acknowledgements: the authors wish to thank the Directors of Veterinary Services and abattoir personnel (Botswana, Namibia, South Africa and Zimbabwe) who made their audit records publicly available to permit this analysis. The authors also thank staff at the Sub-Directorate Epidemiology, Directorate of Animal Health, Department of Agriculture, Forestry and Fisheries, South Africa for kindly creating Figure 1. Map is produced with permission from the Sub-Directorate.

Received for publication: 20 February 2015.

Revision received: 17 March 2015.

Accepted for publication: 17 March 2015

This work is licensed under a Creative Commons Attribution 3.0 License (by-nc 3.0).

(C) Copyright K. Magwedere et al., 2015

Licensee PAGEPress, Italy

Italian Journal of Food Safety 2015; 4:5114

doi:10.4081/ijfs.2015.5114

for food standards and related texts, while OIE is responsible for safeguarding and improving animal health worldwide. However, in many developing countries, statutes relating to these guidelines are largely unchanged and are therefore failing to keep pace with scientific advances in food safety and the changing food supply chains (Olson, 2011). To enforce benchmarks for international harmonisation and equivalents that guarantee a lucrative trade in safe food, Southern African countries (Figure 1) acceded to various international instruments which, when enacted by their parliaments, such international agreements form part of the law of the individual country. These international instruments include the WTO Agreement on the Application of SPS Measures, the various OIE and Codex Alimentarius Commission standards, African Union-Inter-African Bureau for Animal Resources (AU-IBAR) and Article 16 of the Southern African Development Community (SADC) protocol on trade relating to SPS measures (Mukumba, 2011; Kahn and Pelgrim, 2012; AU-IBAR, 2013). While most governments generally prescribe food safety policies, it is the food business operators that are responsible 
for the development, implementation, continual improvement and management of food control systems, and thus, collectively ensuring that national food safety goals are fulfilled (Amadei et al., 2007). To supplement regulatory inadequacy and to create trade barriers, there has been a considerable rise in the number of established private food standards (PFS) over the last decade across the globe (OECD, 2007; UNCTAD, 2007; Liu, 2009). Although the PFS are nominally voluntary, there is a growing concern in developing countries that commercial monopoly of the food industry, particularly within the retail sector, leads to a situation where conformance to private standards can determine market access (FA0, 2010).

\section{Food safety and control in Southern Africa}

Food control can be defined as a mandatory regulatory activity of enforcement by the competent health authority in order to provide consumer protection and ensure that all foods conform to safety requirements during production, handling, storage, processing and distribution and is also honestly and accurately labelled as prescribed by law to be safe, wholesome and fit for human consumption (FAO/WHO, 2003). In a region with an established informal food distribution sector, many national food safety control systems in Southern Africa have failed to provide an adequate level of protection to consumers. This can be viewed as a critical factor in creating barriers to small-scale producers, manufacturers and retailers alike, and thus, impeding the development of a sustainable food-related business (WHO, 2006). Although various Ministries/Departments have a collective responsibility of ensuring food safety at national, provincial and municipal levels, this brings tremendous challenges particularly when a break in the food control chain of command occurs. As the food safety and supply environments are rapidly changing across the world, Southern Africa's multiple regulatory authorities have not been able to respond strategically and re-adapt as a modernized holistic regional system both in terms of integration and coordination. Furthermore, the presence of multiple competent authorities and agencies involved in food control are rendered incompetent by fragmented legislation, organizational structure and functions. Major challenges include lack of political willpower and technical capabilities in the coordination of functions, duplication and sometimes unclear or conflicting jurisdiction of functions within and between the government departments mandated to ensure food safety. Consequently, the impact of most food-borne pathogens and the burden of illnesses in the Southern Africa population remain largely unknown despite a few published indicators
(Grace et al., 2012; NHLS, 2015). A generally weak, fragmented and not so well coordinated food control system is mainly responsible for the failure to adequately protect the health of consumers, which is key to the enhancement of the competitiveness of food exports (FAO/WHO, 2005). Unsurprisingly, no population-based evidence exists to verify the estimates of incidences or distribution of foodborne pathogens and illnesses nationally in most Southern African countries (Govender and Katsande, 2011; NHLS, 2012; Govender et al., 2013). Nonetheless, a pilot study carried out by Stellenbosch University in a local township, found that three out of 75,000 cases of diarrhea were due to food- or water-borne pathogens (NHLS, 2015), indicating a possibly low level of detection. However, it is tempting to speculate that the incidence could have been higher, since many enteric illnesses are often self-diagnosed and self-cured and hence are not reported at health centres. Such underreporting consequently leads to loss of valuable epidemiological data which can be used to formulate strategies for improving current and future integrated public health programs. Additionally, other valuable data remains buried in privately published historical studies and unanalysed data in the government and private sector domains. Globalised world agriculture, trade and tourism have created challenges such that estimates of food-borne illnesses in developed countries alone necessitate further research (CDC, 2013). This review examines general verification audits and inspections of food safety systems of Southern African countries in order to identify and high- light existing deficiencies and knowledge gaps in the food safety assurances and also assesses challenges posed by the introduction of the wildlife meat market for export.

\section{Food safety audits and inspections}

Food safety audit reports and observations were conducted in countries (Figure 1) which have the widest and diverse raw products of animal origin destined for the export markets. Reports and audits for each of the countries analyzed in this review were sourced from online databases given in Table 1. The four components of a national food control system (legislation, competent authority, inspection services and laboratory diagnostic capability) were evaluated for compliance. Most of the audit reports originated from export approved facilities whose products ranged from; wild game, cattle, sheep, goats, poultry, ostrich and manufactured ready-to-eat products as recommended (USDA FSIS, 2012; FVO, 2015; OIE PVS, 2015b). The majority of facilities had certified and uncertified voluntary food safety and quality management systems such as Food Safety System Certification 22000 (FSSC, 2015), IS0 9001:2008 (ISO, 2008), HACCP and ISO 22000 (ISO, 2005). Official and non-official on-farm food safety systems were noted in some of the countries. Additionally, third party audits from the Food and Veterinary Office (FVO) and United States Department of Agriculture Food Safety and Inspection Services (USDA FSIS) were also considered (FVO, 2015; USDA FSIS, 2013).

\section{Observations and common findings \\ Though variations existed in the standard-}

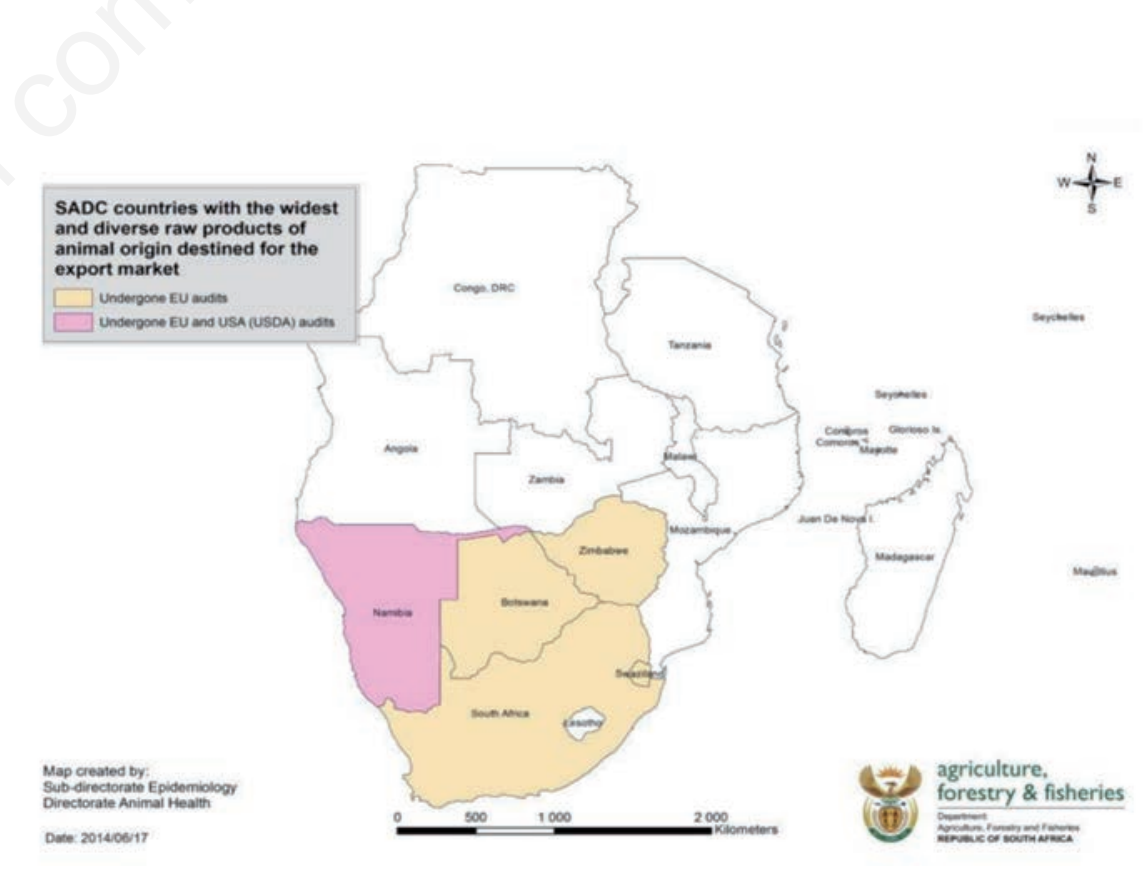

Figure 1. A map of Southern African countries whose food audit reports were accessed and an analysis undertaken. 
ized audit reports, major parameters found to be similar were; i) prerequisite programs and hazard identification protocols, ii) cleaning and disinfection procedures, iii) microbiological and chemical residue sampling (for equipment, environment and food products), iv) hazard analysis and critical control point (HACCP) or hygiene management systems, and v) other aspects related to legislation. The variations, though likely, could not evidently be attributed to the dates when these audits were undertaken (Table 1).

\section{Pre-requisite programmes and the hazard analysis and critical control point}

While good manufacturing practices (GMPs) and pre-requisite programs are primarily designed to maintain operational standards that enhance food safety, the HACCP's strategic focus is on the control and elimination of hazardous biological, chemical and physical matter from the food supply. As such, the HACCP has become an essential component of most food manufacturing operations whether or not its implementation is mandated by legislation (Keener, 2003). The most common problems observed during auditing broadly encompassed a lack of an understanding and familiarity with the methods used to calculate risk posed by food products, especially those based on probability and severity. Confusion on hazards related to animal health and their impact on food safety management systems was common to all approved facilities. In addition, there were deficiencies in providing justification of classifying an identified hazard into specific product categories. Such confusion was frequently encountered where inter-linkages between food safety legislation and voluntary food safety standards had been reconciled to meet requirements of the facility. Furthermore, confusion was visibly evident within the monitoring and verification procedures. Of particular concern, monitoring and verification procedures of critical control points (CCPs) were often confused with those relating to the food safety management systems. To further compound this, there were different authorities tasked with monitoring and verification processes, resulting in numerous inconsistencies. Full-time independent service providers such as meat inspectors and competent authorities had responsibilities for monitoring and verification of audits at some facilities. This is in serious conflict with the HACCP guidelines, which place such responsibilities upon the facility owners and or their representatives. This contributed to a great deal of failure by some facilities especially when justifying and keeping records of all decision-making processes pertaining to: hazard analysis, CCP identification, identification of hazards, risk assessment and corrective actions. Specific differences in the interpretation and use of the decision-tree in the identification of CCPs resulted in inadequate procedures at some facilities. Noteworthy, some facilities tended to identify excessive numbers of CCPs while others lacked any, thereby compromising the process steps essentially required to safeguard human health. Unlike verification, validation was not listed as one of the seven HACCP principles and, in some instances, facilities could not provide validation data or evidence of validation studies having been previously undertaken. Generally, facilities that employed both diversified customer-hired and competent authority regulatory audits had greater food safety compliance in comparison with those lacking any.

\section{Sampling for microbiological or chemical residue analysis}

Due to current and historical trade requirements, microbiological or chemical residue levels in Namibia, Botswana, South Africa and Zimbabwe are based on European Union (EU) standards. Risk-based sampling programs were noted in selected facilities for the microbiological testing of; Salmonella spp., generic

Table 1. Sources of reports and audits of the countries examined and used in this review.

\begin{tabular}{lcc} 
Countryy & On-line source/reference & Date of report \\
\multirow{2}{*}{ Botswana } & OIE PVS evaluation report (OIE PVS, 2015a) & April 2010 \\
& EC Food and Veterinary Office (FVO, 2015) & March 2013 (beef) \\
\multirow{2}{*}{ Namibia } & USDA Foreign Audit report (USDA FSIS, 2009) & January 2011 (meat export) \\
& EC Food and Veterinary Office (FVO, 2015) & March 2013 \\
& OIE PVS Evaluation report (OIE PVS, 2009) & January 2009 \\
\hline South Africa & EC Food and Veterinary Office (FVO, 2015) & January 2011 \\
& & (ratite export) \\
& & October 2008 (food of animal origin) \\
Zimbabwe & OIE PVS evaluation report (OIE PVS, 2015a) & October 2012 \\
& EC Food and Veterinary Office (FVO, 2015) & June 2003 (ratite export) \\
& & January 2001 (meat export) \\
\hline
\end{tabular}

E. coli, E. coli 0157, Staphylococcus aureus, Listeria spp., total viable counts (TVC), coliforms, Pseudomonas spp., other Enterobacteria, Clostridium perfringens, Bacillus cereus, yeasts and moulds. The existence of protocols for sampling these spoilage and zoonotic bacteria on carcasses depended on the facility, industrial standards for the commodity and market requirements. All the facilities relied on national residue programs which abolished the need for a re-assessment of their food safety management systems by competent authorities. Antimicrobial resistance tests were not routinely undertaken at all the facilities visited, though some recently published data could be found in some (Oguttu et al., 2008). All E. coli 0157:H7 isolates from water, meat and meat products, vegetables, stools from confirmed and non-confirmed HIV/AIDS patients were resistant to gentamicin and erythromycin, whilst 75 per cent of the isolates were resistant to ampicillin and tetracycline and $25 \%$ resistant to nalidixic acid, ceftriaxone, and chloramphenicol (Abong'o and Momba, 2008). However, there were no documented procedures to mitigate the possible transmission of antimicrobial-resistant pathogenic bacteria to humans through the food chain. Of serious concern, there was lack of evidence of any validation having been done at most of the facilities to address the food safety concerns arising from E. coli 0157, non-0157 Shiga toxin-producing E. coli (STEC) or other food-borne pathogens. STEC 0157 and non0157 strains are now considered top priority food-borne pathogens since they have been involved in various outbreaks linked to different food matrices around the globe in recent years. Relatively little information exists on the common zoonotic serotypes of $E$. coli and their epidemiology in Southern Africa although serotypes 05, 043, 045, 0103, 0110, 0113 , and 0115 have recently been detected in game meat (Magwedere et al., 2013a, 2013b). Other STEC sero-groups readily encountered in South African food-producing animals include: 026, 055, 0111, 0119, 0127 and 0157 (NHLS, 2011).

Microbiological hazards associated with the consumption of meat are highly acknowledged public health concerns hence prior analysis not only provides a key verification point under the HACCP based system, but also assures the quality of such meat (Magwedere et al., 2013a). In many countries, regulators have increased the focus on improving food safety systems through reducing carriage of pathogens in food-producing animals and/or the subsequent contamination of animal products at harvest. A major focus on the pre- and post-harvest control of bacterial pathogens has been placed on organisms such as STEC and Salmonella within the remit of the HACCPbased protocols. Whilst this may be appropriate 
for livestock species, it is increasingly becoming evident that the scientific basis of the microbiological criteria and contamination levels should be re-visited to address emerging food safety challenges posed by game meat. Further, the lack of local or regional accredited laboratories that can perform serotyping or determine the toxinogenicity of $E$. coli isolates from all sources is a major concern from a regulatory and risk-based food safety perspective.

Apart from STEC, extra-intestinal pathogenic Escherichia coli (ExPEC) are the leading cause of community-acquired urinary tract infections (UTIs) in humans, accounting for $>85 \%$ of UTIs (Bergeron et al., 2012). To this end, chickens are suspected to be the major reservoir of exPEC, thus the zoonotic implications of this group of pathogen is increasingly taking recognition (Mellata, 2013). More worrisome, poultry are also a well-established source of food-borne campylobacteriosis in humans. In South Africa, $32.3 \%$ of the carcasses were reported to harbour Campylobacter, but no significant differences in contamination levels between fresh or frozen samples or within samples from butcheries, supermarkets or street vendors were detected (Mabote $e t$ al., 2011). Surprisingly, more fresh carcasses from butcheries than from other outlets were contaminated with Salmonella, while a greater proportion of fresh carcasses from supermarkets were contaminated with Campylobacter (Mabote et al., 2011). Apart from South Africa, there is very limited published data on the prevalence of Campylobacter spp. in poultry and other animal-derived products in other Southern African countries. However, Campylobacter infections in humans have been widely reported in Botswana (Rowe et al., 2010), Malawi (Mason et al., 2013), Mozambique (Mandomando et al., 2007), Zambia (Luo et al., 1996), Tanzania (Mshana et al., 2013) and in Zimbabwe (Simango and Nyahanana, 1997; Simango and Rukure, 1991; Simango, 2013). Although the sources of such infections were not always identified in these countries, poultry were the likely source of contamination of food and water, thus underscoring the need to improve on existing food control measures.

Screening for Salmonella is part of the food safety requirements for products primarily destined for exports. A retrospective analysis on laboratory diagnostic data of animals and animal products in South Africa for the period 1996-2006 revealed a wide range of Salmonella serovars, with poultry contributing a total of 2410 (70.5\%) of the cases while other birds accounted for 641 cases (18.75\%) (Kidanemariam et al., 2010). Noteworthy, such carriage of Salmonella in food-producing animals has not been linked to human illness. In other countries, the carriage of Salmonella enterica in food-producing animals, including meat from crocodiles, has been reported in Zimbabwe (Madsen et al., 1998; Makanyanga et al., 2014) and in Botswana (Dzoma et al., 2008; Samaxa et al., 2012), but again, there was no evidence linking these to human infections. A recent study in Namibia failed to detect any salmonellae in springbok meat destined for export (Magwedere et al., 2013a). Furthermore, diverse variants within serovars of non-typhoidal Salmonella enterica strains, not linked to foodborne illnesses, have recently been detected in Zimbabwe (Paglietti et al., 2013), emphasising the need for stronger surveillance and monitoring programs. Nonetheless, with increasing global trade, this highlights the potential risk that should be considered within the regulation framework of food derived from animals.

\section{Constraints affecting microbiologi- cal or chemical residue analysis in meat}

Testing for the presence of harmful substances and potential pathogens within the food supply chain serves an important role in guaranteeing the safety of food. Although food safety professionals ensure the execution of food safety requirements, it is the laboratory evidence that declares the food as safe, which may be misleading since analysis is based on samples randomly collected from the carcasses. Sampling and testing for contaminants or hazards can give assurances of working protocols within the food hygiene control programs, but the laboratory resources and capability are of prime importance in ascertaining food safety. Furthermore, accreditation for food analytical tests is essential to guaranteeing food safety in all officially recognised laboratories as recommended (SADCAS, 2013). In most southern African countries, there is a limited number of official laboratories with accredited analytical methods for the quantification of common bacterial and chemical hazards associated with foods derived from animals. As such, there is an urgent need to implement integrated laboratory quality management systems and training to standardise various food testing methodologies in the current food and veterinary laboratories (Frean et al., 2012). Establishment of auditing and inspection programmes as well as proficiency tests should be considered. This can be enhanced if Ministries and Departments work in collaboration with OIE/FA0 reference laboratories and other relevant international organisations. Priority should be given to the development of a regional integrated laboratory systems which may address common anomalies in laboratories always observed throughout the region. This will ensure standardisation of testing methods, accreditation of food testing laboratories, certifiers and the establishment of laboratory quality assurance auditors across the region.

\section{Species-specific detection tests for} meat

Specification of the type of meat is an area that needs specialized attention in the food quality assurance system to ensure compliance with the food laws. Though phenotypic qualitative tests are commonly undertaken, these alone may be inadequate in correctly identifying the species origin of the meat. Definitive identification requires molecular techniques like species-specific DNA tests, and these are rarely done in Southern Africa (Singh and Neelam, 2011). Despite SADC being a net exporter of livestock products (Tui et al., 2013), the main challenge facing the regulatory competent authorities is a lack of laboratories and information on the expected levels of cross-species contamination at diverse abattoirs, processors and retailers that handle animal and animal products prior to reaching the consumer. Nevertheless, multispecies DNA traces in processed animal products have been encountered (Food Law Latest, 2013a), and therefore calls for an urgent need to establish acceptable contamination levels in the regional food industries to enable unpicking unintentional from deliberate adulteration (Cawthorn et al., 2013; D'Amato et al., 2013). However, accurate, efficient and rapid routine sample analysis can be achieved through the implementation of validated and accredited diagnostic protocols.

\section{Food safety and quality concerns associated with game meat}

Standard practice dictates that the impact of regulatory measures can only be assessed after such regulations have been enforced. Harvested game carcasses originating from OIE-declared foot and mouth disease (FMD)free zones are routinely subjected to temperatures above $+2^{\circ} \mathrm{C}$ for at least 24 hours (maturation) before the bones are removed. Deboning of meat is a pre-requisite strategy to control spread of pathogens that might be transmitted through bone-marrow like the FMD virus. However, undertaking this process in countries with hot temperatures can inadvertently impose quality and safety concerns on game meat resulting in unfair and excessive trade restrictions. Regulatory emphasis on a pH of less than 6.0 at 24 hours post-harvest and a good harvesting practice guide on temperatures above $+2^{\circ} \mathrm{C}$ for at least 24 hours have been recommended to improve the quality and safety of game meat (European Commission, 2010; Pharo, 2002). Analytical studies targeting cooling regimes in the chilling truck and their relationships to loading densities, species and time should generate data for formulating guidelines that can improve the quality of meat. The current mat- 
uration requirements prohibit the harvesters from reducing cooling truck temperatures to achieve carcass temperatures of below $7^{\circ} \mathrm{C}$ within 24 hours of harvesting. Temperatures below $7^{\circ} \mathrm{C}$ are recommended for controlling potential bacteriological hazards in game meat and offal and therefore a core temperature of less than $7^{\circ} \mathrm{C}$ on carcasses and red offal should be achieved within 16 hours. As such, red offal (lungs, heart, liver, spleen and tongue) normally hang with the carcass for synchronization purposes at the harvesting field abattoir whereas rough offal (stomach and intestines) are stored at an air temperature not exceeding minus $2^{\circ} \mathrm{C}$ (Republic of South Africa, 2000). However, some competent authorities tend to focus more on electronic readings on cooling trucks and chilling temperature records as indicators of compliance, which may not be reflected on individual carcasses. Instances like these often compromise the quality and safety of game meat. Cooling of game carcasses to desired temperatures may be hampered by factors such as aponeuroses which firmly surround the muscles and the thick hairy skin (Paulsen, 2011). In some instances, maturation starts at the export abattoir and this negatively impacts on the colour, stability and shelf life of the meat.

Despite zoonoses posing a potential threat to the sustenance of the wildlife industry (Magwedere et al., 2012), there is a spiralling wildlife meat industry primarily targeting the lucrative European market. However, there are inevitably serious concerns on food quality and safety and these have become critical issues for the industry. As such, the sanitary aspects of game meat in the region are now given a top priority. Although extensive work has been undertaken on parameters required for a sustainable game meat industry (van Schalkwk, 2011), there are some knowledge gaps on the safe production practices. Indeed, some guidelines for the production of safe game meat for export now exist (van Schalkwk and Hoffman, 2010), but these have not been thoroughly examined or tested. It is clear slaughter practices of free-ranging wildlife are different from those of livestock species, thus concerns on meat quality and safety continue to present a challenge to the existing regulatory framework of the meat industry. There is a need to develop new legislation that cater for the slaughter and processing of wildlife especially those from free-ranging as opposed to those managed or farmed. Farmed wildlife is confined to conservancies where they are protected from predation and more importantly, limited disease control measures can be applied, whereas freeranging wildlife is prone to predation and disease control measures are difficult to institute. Slaughter of such animals is by free bullet, often during nocturnal hunting sessions. The level of contamination on the hide and subse- quently on the carcass depends on where the shot animal falls. Contamination of the carcasses upon skinning and evisceration is inevitable as these are done on the field, where water and availability of disinfectants may be limiting. This effectively impacts on the prescribed limits of both spoilage and pathogenic bacteria on such carcasses, particularly if destined for export. Meat destined for local consumption is not usually subjected meat safety regulations. It is worthy to note that by applying EU game meat safety and quality standards on game meat harvested in South Africa for the local consumption, the level of microbiological contamination was found to be significantly higher in such meat (Van der Merwe et al., 2011), highlighting a potential risk to the consumer. It is within this context that the microbiological levels of wildlife carcasses should be revised based on scientific evidence which does not compromise the quality and safety of such meat. Additionally, some bullets contain traces of lead $(\mathrm{Pb})$ and other heavy metals which may contaminate the wildlife carcasses or the environment during hunting. We have reported that some liver samples from free-ranging springbok slaughtered for consumption had $\mathrm{Pb}$ concentrations above the accepted limit, implying a potential chemical risk to humans (Magwedere et al., 2013c). Therefore, the development of a new regulatory framework catering for game meat should take into consideration these potential factors which may impinge on current limits of biological and chemical hazards.

\section{Discussion}

Sub-standard food safety regulations and practices are a key hindrance to increasing the competitiveness of food producers across the regional communities in Africa. Food safety audits and inspections provide information about the efficacy of a facility's food safety process control system at any point in time (Ollinger et al., 2011). Third party auditors usually have no legal powers, hence their work simply puts commercial pressure (threat of losing business or reducing the opportunity of gaining new business) on facilities in terms of them failing an audit or getting multiple nonconformities. An effective auditing and inspection strategy requires clear inspection policies and procedures that are evenly applied across all food premises by competent inspectors without compromising safety standards within the food industries. Unfortunately, no standardised competency-based regulatory food inspection and auditing services exist in southern Africa (Powell et al., 2013). The majority of existing qualified auditors are not located in small towns or rural areas where abattoir facilities in those areas cannot afford auditing services. Most of the rural facilities are subject to no audits since they are unregistered and even if registered, they principally serve customers who do not demand such audits. Moreover, these facilities are owned by people who see no need for audits since they have been operating for several years without any adverse food safety report or incidence.

In light of the changing environment in food safety assurances, some governments have responded by pursuing flexible preventative efforts in a complex global food supply and have started upgrading their inspection systems, in both quality and quantity to meet national and international needs (Parliamentary Monitoring Group, 2013b). It is worthy to note that South Africa has introduced a national abattoir rating scheme (NARS) which is dependent on a number of factors. Under this scheme, facilities can receive a favorable rating if they meet the stipulated standards for food safety. However, a favorable rating does not always necessarily translate into a facility that produces safe and wholesome food since a good rating is dependent and influenced by other factors (DAFF, 2013; Ollinger et al., 2011). In trial runs of the NARS scheme, a lack of proper standardization with respect to the conversion of qualitative to quantitative aspects or scores resulted in highly variable error margins and therefore was deemed to be unreliable. Other concerns were the legality of regulators awarding some points to facilities with partial compliance in all the aspects of the food laws. Validation of the hygiene management system (HMS) and hygiene assessment system (HAS), for example, through correlation of hazards in meat samples with the HMS as a control system and HAS as an accurate predicator of abattoir hygiene has not been comprehensively undertaken nationally (Govender et al., 2013). This was necessitated by the fact that most of the food safety management systems programs were not linked in a holistic whole chain approach that extends from farm to fork in order to provide a full guarantee of safe meat or animal products (Govender and Katsande, 2011; McDermott et al., 2010). To some extent, the enforcement of on-farm food safety systems has been market-driven and also speciesdependent (Meat Board of Namibia, 2010; DAFF, 2012). Lack of proper training of the onfarm auditors was noted, making compliance assessments difficult to undertake. The application of on-farm GMPs and/or HACCP requires a level of management sophistication that is not always available to the different livestock farming system (communal, commercial and resettled) levels. In some instances, the on-farm program did not address environmental sanitary impact on livestock farming and to that effect, no documented verification 
system was noted (Meat Board of Namibia, 2010). Classification of on-farm food safety members into provisional and certified members if introduced could assist competent authorities in reviewing of food chain information at harvesting and slaughterhouses (Olson, 2011). While sanitary SPS issues are an increasingly important barrier to SADC countries' intra-regional trade in food and agricultural products, they also impinge on the geographical diversification of exports, including the development of international markets.

\section{Conclusions}

In conclusion, the availability of prescribed food safety management systems does not guarantee prevention of contamination of the meat and animal products unless it is combined with efficient and effective implementation (Govender et al., 2013; Tshabalala, 2011). Concerning risk assessments and precautionary principles, there is scope for scientific research to significantly contribute to the facilitation of trade. A risk profile of microbial hazards across the supply continuum for the poultry, game, beef, sheep and goat meat industries should be developed. Factors contributing to food safety risk and risk ranking of various product/pathogen combinations should be highlighted in southern Africa. Development of regionally harmonized risk-based verification steps throughout the food safety system and recognition of third-party verification audits aligned to competent authorities' requirements could potentially complement regulatory authorities' responsibilities as most governments are currently over-stretched by a lack of personnel and resources. Perhaps, adoption of the SAFE FOODs framework, which incorporates the critical steps of framing, risk assessment, evaluation, risk management, and review as prescribed (Knudsen, 2010), will diminish challenges related to the sanitary compliance. Thus, a continuous review of food safety regulations is necessary to keep pace with the changing food supply, scientific advances and the demand to safeguard human health.

\section{References}

Abong'o B0, Momba MN, 2008. Prevalence and potential link between E. coli 0157:H7 isolated from drinking water, meat and vegetables and stools of diarrhoeic confirmed and non-confirmed HIV/AIDS patients in the Amathole District - South Africa. J Appl Microbiol 105:424-31.

Amadei P, Biondi A, Tarsitani G, Antonini A,
2007. Outlook and problems of microbiological sampling in public catering establishments in light of the new European regulations. Igiene e Sanità Pubblica 63:377-90.

AU-IBAR, 2013. Second continental workshop on the missions, functions and structure of African Union Food Safety Authority and a rapid alert system for food and feed. Available from: http://www.au-ibar.org/panspso/399-second-continental-workshopon-the-missions-functions-and-structureof-african-union-food-safety-authorityand-a-rapid-alert-system-for-food-and-feed

Bergeron CR, Prussing C, Boerlin P, Daignault D, Dutil L, Reid-Smith RJ, Zhanel GG, Manges AR, 2012. Chicken as reservoir for extraintestinal pathogenic Escherichia coli in humans, Canada. Emerg Infect Dis 18:3.

Cawthorn D-M, Steinman HA, Hoffman LC, 2013. A high incidence of species substitution and mislabelling detected in meat products sold in South Africa. Food Control 32:440-9.

Centers for Disease Control and Prevention, 2013. CDC Estimates of foodborne illness in the United States. Available from: http://www.cdc.gov/foodborneburden/

DAFF, 2012. Available from: http://www.nda.agric.za/vetweb/NPN\%20\& $\begin{array}{lllllllllll}\% & 2 & 0 & \mathrm{~S} & 0 & \mathrm{P} & / & 0 & 0 & 4 & -\end{array}$ VPN\%2004\%20Standards\%20for\%20the $\% 2$ Oregistration $\% 20$ of $\% 20$ ostrich $\% 20$ farm $\% 2$ 0for\%20export.pdf

DAFF, 2013. Abattoir rating scheme. Available from: http://www.gov.za/documents/meatsafety-act-abattoir-rating-scheme-proposal

D'Amato ME, Alechine E, Cloete KW, Davison $\mathrm{S}$, Corach D, 2013. Where is the game? Wild meat products authentication in South Africa: a case study. Available from: http://www.investigativegenetics.com/content/4/1/6

Dzoma BM, Sejoe S, Segwagwe BV, 2008. Commercial crocodile farming in Botswana. Trop Anim Health Pro 40:37781.

EFSA, 2010. Panel on Biological Hazards (BIOHAZ). Scientific opinion on quantification of the risk posed by broiler meat to human campylobacteriosis in the EU. EFSA J 8:1437.

European commission, 2010. Regulation laying down lists of third countries, territories or parts there of authorized for the introduction into the European Union of certain animals and fresh meat and the veterinary certification requirements, 206/2010/EC. In: Official Journal, L 73/1-120.

FA0, 2006. Making rights a reality. Available from: http://www.fao.org/focus/e/rightfood/right2.htm
FA0, 2010. Private food safety standards: their role in food safety regulation and their impact. Available from: http://www.fao.org/docrep/016/ap236e/ap23 6e.pdf

FAO/WHO, 2003. Assuring food safety and quality: guidelines for strengthening national food control systems. Available from: http://www.fao.org/docrep/006/y8705e/y870 $5 \mathrm{e} 00 . \mathrm{htm}$

FAO/WHO, 2005. National food safety systems in Africa - a situation analysis. Available $\begin{array}{lllll}\mathrm{f} & \mathrm{r} & 0 & \mathrm{~m}\end{array}$ ftp://ftp.fao.org/docrep/fao/meeting/010/j61 22e.pdf

Food Law Latest, 2013a. Available from: http://foodlawlatest.com/2013/04/09/mafiashadow-on-the-italian-food-business-economic-implications

Frean J, Perovic 0, Fensham V, McCarthy K, Von Gottberg A, De Gouveia L, Poonsamy B, Dini L, Rossouw J, Keddy K, Alemu W, Yahaya A, Pierson A, Dolmazon V, Cognat S, Ndihokubwayo JB, 2012. External quality assessment of national public health laboratories in Africa, 2002-2009. B World Health Organ 90:191-9.

FSSC, 2015. Available from: http://www.fssc22000.com/documents/hom e.xml?lang=en

FVO, 2015. Available from: http://ec.europa.eu /food/fvo/audit_reports/index.cfm

Govender R, Katsande TC, 2011. ISO/IEC 17020 accreditation of Gauteng Veterinary Services: a systems approach towards managing food safety in South Africa. Int J Food Safety Nutr Pub Health 4:175-95.

Govender R, Naidoo D, Buys EM, 2013. Managing meat safety at South African abattoirs. Int $\mathrm{J}$ Biol Vet Agr Food Eng 7:124-9.

Grace D, Mutua F, Ochungo P, Kruska R, Jones K, Brierley L, Lapar L, Said M, Herrero M, Phuc PM, Thao NB, Akuku I, Oguttu F, 2012. Mapping of poverty and likely zoonoses hotspots. Available from: http://mahider.ilri.org/handle/10568/21161

ISO, 2005. Food safety management systems. Requirements for any organization in the food chain. ISO Norm 22000:2005. International Organization for Standardization, Geneva, Switzerland.

ISO, 2008. Quality management systems. Requirements. ISO Norm 9001:2008. International Organization for Standardization, Geneva, Switzerland.

Kahn S, Pelgrim W, 2010. The role of the World Trade Organization and the 'three sisters' (the World Organisation for Animal Health, the International Plant Protection Convention and the Codex Alimentarius Commission) in the control of invasive alien species and the preservation of biodiversity. Rev Sci Tech 29:411-7. 
Keener L, 2003. The total plant food safety audit: rating your overall system. Available from: http://www.foodsafetymagazine. com/magazine-archive $1 /$ december2002january-2003/the-total-plant-foodsafety-audit-rating-your-overall-system/

Kidanemariam A, Engelbrecht M, Picard J, 2010. Retrospective study on the incidence of Salmonella isolations in animals in South Africa, 1996 to 2006. J S Afr Vet Assoc 81:37-44.

Knudsen I, 2010. The SAFE F00DS framework for integrated risk analysis of food: an approach designed for science-based, transparent, open and participatory management of food safety. Food Control 21:1653-61.

Liu P, 2009. Private standards in international trade: issues, opportunities and long-term prospects. FAO, Rome, Italy.

Luo NP, Baboo KS, Mwenya D, Diab A, Perera CU, Cummings C, Dupont HL, Murphy JR, Zumla A, 1996. Isolation of Campylobacter species from Zambian patients with acute diarrhoea. E Afr Med J 73:395-6.

Mabote KI, Mbewe M, Ateba CN, 2011. Prevalence of Campylobacter contamination in fresh chicken meat and milk obtained from markets in the North-West Province, South Africa. J Hum Ecol 36:238.

Madsen M, Hangartner P, West K, Kelly P, 1998. Recovery rates, serotypes, and antimicrobial susceptibility patterns of salmonellae isolated from cloacal swabs of wild Nile crocodiles (Crocodylus niloticus) in Zimbabwe. J Zoo Wildlife Med 29:31-4.

Magwedere K, Dang HA, Mills EW, Cutter CN, Roberts EL, DeBroy C, 2013a. Incidence of Shiga toxin-producing Escherichia coli strains in beef, pork, chicken, deer, boar, bison, and rabbit retail meat. J Vet Diagn Invest 25:254-8.

Magwedere K, Hemberger MY, Hoffman LC, Dziva F, 2012. Zoonoses: a potential obstacle to the growing wildlife industry of Namibia. Infect Ecol Epidemiol 2:18365.

Magwedere K, Shilangale R, Mbulu RS, Hemberger Y, Hoffman LC, Dziva F, 2013b. Microbiological quality and potential public health risks of export meat from springbok (Antidorcas marsupialis) in Namibia. Meat Sci 93:73-8.

Magwedere K, Shimwino J, Hemberger Y, Hoffman LC, Midzi EM, Dziva F, 2013c. Lead and cadmium levels in liver, kidney and muscle of harvested wild springbok (Antidorcus marsupialis) under extensive management in Southern and SouthEastern Namibia. S Afr J Wildl Res 43:5260.

Makanyanga TB, Mutema G, Mukarati NL, Chikerema SM, Makaya PV, Musari S, Matope G, 2014. Microbial quality of frozen
Nile crocodile (Crocodylus niloticus) meat samples from three selected farms in Zimbabwe. Int J Food Microbiol 170:44-7.

Mandomando IM, Macete EV, Ruiz J, Sanz S, Abacassamo F, Vallès X, Sacarlal J, Navia MM, Vila J, Alonso PL, Gascon J, 2007. Etiology of diarrhea in children younger than 5 years of age admitted in a rural hospital of southern Mozambique. Am J Trop Med Hyg 76:522-7.

Mason J, Iturriza-Gomara M, O'Brien SJ, Ngwira BM, Dove W, Maiden MC, Cunliffe NA, 2013. Campylobacter infection in children in Malawi is common and is frequently associated with enteric virus coinfections. PLoS One 8:e59663.

McDermott JJ, Staal SJ, Freeman HA, Herrero M, Van de Steeg JA, 2010. Sustaining intensification of smallholder livestock systems in the tropics. Livest Sci 130:95109.

Meat Board of Namibia, 2010. Available from: http://www.nammic.com.na/fan.php

Mellata M, 2013. Human and avian extraintestinal pathogenic Escherichia coli: infections, zoonotic risks, and antibiotic resistance trends. Foodborne Pathog Dis 10:91632 .

Mshana SE, Matee M, Rweyemamu M, 2013. Antimicrobial resistance in human and animal pathogens in Zambia, Democratic Republic of Congo, Mozambique and Tanzania: an urgent need of a sustainable surveillance system. Ann Clin Microb Antimicrob 12:28.

Mukumba C, 2011. An analysis of Southern Africa's food safety standards within the broader framework set by the WTO's SPS measures: a South African case study. Degree Diss. Faculty of Arts, University of the Witwatersrand, Johannesburg, South Africa.

Mukumba C, Hornsby DJ, 2011. The international food safety complex in Southern Africa: cooperation or conflict? S Afr J Int Affairs 18:235-56.

NHLS, 2011. Group for enteric, respiratory and meningeal disease surveillance in South Africa. GERMS-SA annual report 2011. Available

from: http://www.nicd.ac.za/assets/files/2011_GE RMS-SA_Annual_report_pub_final.pdf

NHLS, 2012. National Institute for Communicable Diseases. Annual review 2011-2012. Available from: http://www.nhls.ac.za/assets/files/NICD\%2 0Annual\%20Review(1).pdf

NHLS, 2015. Food scare. Available from: http://www.nhls.ac.za/?page $=$ news $\& i d=4 \&$ rid $=35$

OECD, 2007. Private standard schemes and developing country access to global value chains: challenges and opportunities emerging from four case studies.
Organisation of Economic Co-operation and Development, Paris, France.

Oguttu JW, Veary CM, Picard JA, 2008. Antimicrobial drug resistance of Escherichia coli isolated from poultry abattoir workers at risk and broilers on antimicrobials. J S Afr Vet Assoc 79:161-6.

OIE PVS, 2009. Available from: http://www.oie.int/fileadmin/Home/eng/Su pport_to_OIE_Members/docs/pdf/Namibia _OIE-PVS_28012009.pdf

OIE PVS, 2015a. Available from: http://www.oie.int/support-to-oie-members/pvs-evaluations/oie-pvs-evaluationreports/

OIE PVS, 2015b. Available from: http://www.oie.int/support-to-oie-members/pvs-evaluations/status-of-missions/

Ollinger M, Muth MK, Karns SA, Choice Z, 2011. Food safety audits, plant characteristics, and food safety technology use in meat and poultry plants. Available from: http://www.ers.usda.gov/media/115077/eib 82_1_.pdf

Olson ED, 2011. Protecting food safety: more needs to be done to keep pace with scientific advances and the changing food supply. Health Affair 30:915-23.

Paglietti B, Falchi G, Mason P, Chitsatso 0, Nair S, Gwanzura L, Uzzau S, Cappuccinelli P, Wain J, Rubino S, 2013. Diversity among human non-typhoidal salmonellae isolates from Zimbabwe. T Roy Soc Trop Med H107:487-92.

Parliamentary Monitoring Group, 2013. Meat inspections \& labeling in SA: Department of Agriculture, Health, Trade \& Industry, Stellenbosch \& Western Cape Universities. Available from: http://www.pmg.org.za/report/20130326meat-inspections-labeling-sa-depts-agriculture-health-trade-industry

Paulsen P, 2011. Hygiene and microbiology of meat from wild game: an Austrian view. In: Paulsen P, Bauer A, Vodnansky M, Winkelmayer R, Smulders FJM, eds. Game meat hygiene in focus. Wageningen Academic Publishers, Wageningen, The Netherlands, pp 19-33.

Pharo HJ, 2002. Foot-and-mouth disease: an assessment of the risks facing New Zealand. New Zeal Vet J 50:46-55.

Powell DA, Erdozain S, Dodd C, Costa R, Morley K, Chapman BJ, 2013. Audits and inspections are never enough: a critique to enhance food safety. Food Control 30:68691.

Republic of South Africa, 2000. Meat Safety Act, 2000 (Act No. 40 of 2000). Available from: http://www.nda.agric.za/doaDev /sideMenu/APIS/doc/MEATSAFETY.pdf

Rowe JS, Shah SS, Motlhagodi S, Bafana M, Tawanana E, Truong HT, Wood SM, Zetola NM, Steenhoff AP, 2010. An epidemiologic 
review of enteropathogens in Gaborone, Botswana: shifting patterns of resistance in an HIV endemic region. PLoS One 5:e10924.

SADCAS, 2013. Available from: http://www.sadcas.org/allnews.php

Samaxa RG, Matsheka MI, Mpoloka SW, Gashe BA, 2012. Prevalence and antimicrobial susceptibility of Salmonella isolated from a variety of raw meat sausages in Gaborone (Botswana) retail stores. Food Protect 75:637-42.

Simango C, 2013. Antimicrobial susceptibility of Campylobacter species. S Afr J Epidemiol Infect 28:139-42.

Simango C, Nyahanana M, 1997. Campylobacter enteritis in children in an urban community. Cent Afr J Med 43:1725.

Simango C, Rukure G, 1991. Potential sources of Campylobacter species in the homes of farm workers in Zimbabwe. J Trop Med Hyg 94:388-92.

Singh VP, Neelam S, 2011. Meat species specifications to ensure the quality of meat. A review. Available from: http://scialert.net/fulltext/?doi=ijmeat.201 1.15.26\&org $=11$

STDF, 2011. An overview of tools developed by international organizations to evaluate sanitary and phytosanitary (SPS) capacity. Available from: http: http://www.oie.int/doc
/ged/D13279.PDF

Thompson D, Ying H, 2007. Food safety in China: new strategies. Available from: http://www.cftni.org/publications/Thompso n.pdf

Tshabalala PA, 2011. Effect of food safety systems on the microbiological quality of beef. PhD thesis, Department of food Science, University of Pretoria, South Africa. Available from: http://repository.up. ac.za/bitstream/handle/2263/28854/Compl ete.pdf?sequence $=6$

Tui SHK, van Rooyen AF, Minde I, 2013. Available from: http://www.icrisat.org/locations/esa/esa-publications/National-andRegional-markets-livestock-marketsopportunities-growth-SADC.pdf

UNCTAD, 2007. Food safety and environmental requirements in export markets. Friend or foe for producers of fruit and vegetables in Asian developing countries? United Nations Conference on Trade and Development, Geneva, Switzerland.

USDA FSIS, 2009. Available from: http:/www.fsis.usda.gov/wps/portal/fsis/to pics/international-affairs/importing-products/eligible-countries-products-foreignestablishments/foreign-audit-reports

USDA FSIS, 2012. Available from: http://www.fsis.usda.gov/wps/portal/fsis/to pics/international-affairs/importing-products/equivalence/status-of-initial-equiva- lence/namibia-initial-equivalence-status

USDA FSIS, 2013. Available from: http://www.fsis.usda.gov/wps/portal/frameredirect?url=/wps/wcm/connect/FSISContent/fsis-questionable-content/foreign-audit-reports-duplicate

Van der Merwe M, Jooste PJ, Hoffman LC, 2011. Application of European standards for health and quality control of game meat on game ranches in South Africa. J S Afr Vet Assoc 82:170-5.

Van Schalkwyk DL, 2011. Investigation into selected parameters required to develop a sustainable Namibian game meat industry. PhD Diss. Stellenbosch University, Stellenbosch, South Africa.

Van Schalkwyk DL, Hoffman LC, 2010. Guidelines for the harvesting of game for meat export. Ministry of Agriculture, Water and Forestry, Windhoek, Namibia.

WHO, 2006. Food safety and nutrition. Food law guidelines. Available from: http://www.afro.who.int/en/clusters-a-programmes/hpr/food-safety-and-nutritionfan/fan-publications.html

WTO, 1995. The WT0 agreement on the application of sanitary and phytosanitary measures (SPS agreement). Available from: http://www.wto.org/english/tratop_e/sps_e/ sps_e.htm 